\title{
Beta-Cell Function Measurement
}

National Cancer Institute

\section{Source}

National Cancer Institute. Beta-Cell Function Measurement. NCI Thesaurus. Code C123455.

The determination of the beta cell function (insulin production and secretion) in a biological specimen. 